\title{
EFFECTS OF TEMPERATURE ON BODY CHEMICAL COMPOSITION AND INCIDENCE OF DEFORMITIES IN JUVENILE TENCH, TINCA TINCA (ACTINOPTERYGII: CYPRINIFORMES: CYPRINIDAE), FED A COMMERCIAL DRY DIET AND/OR NATURAL FOOD
}

\author{
Rafał KAMIŃSKI ${ }^{1 *}$, Justyna SIKORSKA ${ }^{1}$, Lucyna POLAK-JUSZCZAK ${ }^{2}$, and Jacek WOLNICKI ${ }^{1}$ \\ ${ }^{1}$ Pond Fishery Department, the Stanistaw Sakowicz Inland Fisheries Institute in Olsztyn, Żabieniec, Poland \\ ${ }^{2}$ Department of Food and Environmental Chemistry, National Marine Fisheries Research Institute, Gdynia, Poland
}

Kamiński R., Sikorska J., Polak-Juszczak L., Wolnicki J. 2017. Effects of temperature on body chemical composition and incidence of deformities in juvenile tench, Tinca tinca (Actinopterygii: Cypriniformes: Cyprinidae), fed a commercial dry diet and/or natural food. Acta Ichthyol. Piscat. 47 (1): 63-71.

Background. Water temperature is a major factor regulating fish metabolism. It can influence body chemical composition and the incidence of body deformities. The latter often develop in farmed fish and this issue is currently emerging as a serious problem for aquaculture. Determining the effects of water temperature on body chemical composition and fish body deformities is an important subject for research in fish biology and nutrition, and aquaculture. The presently reported study was conducted using juvenile tench, Tinca tinca (Linnaeus, 1758), an important aquaculture species in Europe. Two hypotheses were tested: 1) temperature can significantly influence body chemical composition and the incidence of body deformities in fish; 2) the effects of temperature on fish depend on their diet.

Material and methods. Fish, with an initial total length of $28.4 \pm 2.7 \mathrm{~mm}$ and body weight of $0.24 \pm 0.07 \mathrm{~g}$, were reared at 20, 23, and $26^{\circ} \mathrm{C}$ and fed dry feed Aller Futura (Aller Aqua, Denmark) only, or a combination of this feed and natural food (frozen larvae of Chironomidae) in a $3 \div 2$ ratio of dry matter, or the natural food alone. The duration of the experiment and the daily food rations were adjusted to the experimental temperatures based on a correction factor, $q$, of $1.000,0.779$, or 0.609 , respectively. The experiment duration was 92,72 , or 56 days for the respective temperatures.

Results. Body deformities occurred in all groups of fish fed solely or partially with the dry diet $(21.5 \%-89.5 \%)$. The incidence of deformities was directly proportional to the temperature and the content of dry feed in the diet reaching the maximum in fish fed exclusively the dry diet at $26^{\circ} \mathrm{C}$. Water temperature and fish diet influenced body chemical parameters (moisture, protein, lipid, ash, $\mathrm{Ca}, \mathrm{P}, \mathrm{Mg}, \mathrm{Ca} \div \mathrm{P}, \mathrm{Mg} \div \mathrm{P}$ ), but water temperature did not have a significant effect on whole-body $P$ content.

Conclusions. Water temperature proved to significantly influence fish chemical body composition and the incidence of body deformities in fish fed dry diet. The major factor that caused fish P deficiency, and resulted in low body ash content and body deformities, was insufficient bioavailability of $\mathrm{P}$ in the dry diet. Water temperature appeared to only modify P deficiency symptoms in fish.

Keywords: fish, food utilization, growth, nutrition, phosphorus

\section{INTRODUCTION}

Water temperature is a major factor regulating fish metabolic rates, energy expenditure, food intake, and nutritional efficiency. Metabolic rate increases exponentially with temperature, and, at any given temperature, the difference between the energy gained by fish via food intake and the energy consumption by metabolism determines the resources available for growth (Brett and Groves 1979). For cultured fish species, these are key parameters to maximize the efficiency with which consumed food is converted into body growth (Jobling 1994).
Increasing the water temperature results in an increase in the standard metabolic rate (SMR) up to a certain level from which a further increase in temperature depresses the metabolism. Fish growth tends to increase as the water temperature increases within an optimum range of water temperatures for the growth of a given species (Sadler et al. 1986). For early juvenile tench, Tinca tinca (Linnaeus, 1758), a temperature range of $28-31^{\circ} \mathrm{C}$ is considered optimal for growth (Peňáz et al. 1989, Wolnicki and Korwin-Kossakowski 1993). However, the optimum water temperature for food utilization is generally slightly 
lower than the optimum water temperature for growth, which is a widely-described phenomenon (Jobling 1994, Björnsson and Tryggvadóttir 1996, Imsland et al. 2006).

In fish, the temperature influences not only metabolism and growth, but all physiological processes such as ontogenetic development and physiological age (Craig 1985, Kamler 1992). Temperature simultaneously influences different parameters; however, they often respond nonlinearly and unevenly. This makes it difficult to describe precisely the shape of the temperature-effect relation. Probably as a result, the research on finfish aquaculture has often focused on understanding the effects of temperature on growth and food efficiency parameters in relation to diet and duration of the experiment, rarely considering temperature as an important factor for the biological quality of fish. Hence, important questions regarding the influence of water temperature on fish body chemical composition and body deformities have often been ignored. Recently, the tendency of intensive aquaculture to produce fish of low biological quality, including those with body deformities, has become a problem of major importance (Witten et al. 2009, Boglione et al. 2013a, 2013b). In tench, an increasingly important aquaculture species, this problem is very common (Rennert et al. 2003, Wolnicki et al. 2003, 2006, Kamler et al. 2006, Celada et al. 2009, García et al. 2010, González-Rodríguez et al. 2014).

Therefore, this study aimed to test the hypothesis that water temperature can significantly influence not only the growth and food conversion ratio, but also the chemical composition and the incidence of body deformities in tench juveniles fed different diets under controlled conditions.

\section{MATERIALS AND METHODS}

Fish. Tench larvae were obtained from the Samoklęski Fish Farm (SE Poland), a commercial hatchery. Before the commencement of this study, the fish were reared in a recirculating aquaculture system at $25^{\circ} \mathrm{C}$ for five months. For the initial six weeks of external feeding, fish were fed with live Artemia nauplii. For the remainder of the time before the experiment began they were fed chopped frozen Chironomidae larvae. At stocking, juveniles $(28.4 \pm 2.9$ mm TL, $0.24 \pm 0.07 \mathrm{~g} \mathrm{BW}$, mean \pm SD) were pre-selected to minimize variability in body size. Nine groups of 45 fish were stocked into $20 \mathrm{~L}$ experimental aquaria. They were acclimated to the experimental conditions for one week, during which they were fed $5 \mathrm{~g}$ of Chironomidae larvae per aquarium, daily. During the last $24 \mathrm{~h}$ of the acclimation period, water temperatures were gradually adjusted from $25.0^{\circ} \mathrm{C}$ to the target experimental temperatures of 20.0 , 23.0 , and $26.0^{\circ} \mathrm{C}$.

Diet and feeding. One of the objectives of the study was to test the hypothesis that the effects of temperature on fish depend on their diet. Therefore, fish were fed distinctly different diets: a commercial starter feed for fish (Aller Futura 2; Aller Aqua, Denmark; diet F; Table 1), a commercial natural food (frozen Chironomidae larvae, Katrinex, Poland; diet C), and a combined diet composed of diet $\mathrm{F}$ and $\operatorname{diet} \mathrm{C}$ in a ratio of about $3 \div 2$, with respect to dry matter content (diet FC). Diets were stored frozen $\left(-20^{\circ} \mathrm{C}\right)$. Prior to feeding, the dry diet was refrigerated at $4^{\circ} \mathrm{C}$ for $1-7$ days and Chironomidae larvae were thawed at about $20^{\circ} \mathrm{C}$ for $2-3$ min before feeding. Feeding was performed every $3 \mathrm{~h}$ between 08:00 and 20:00 (Table 2). Daily feeding rates were adjusted to the rearing temperatures according to Krogh's normal curve (Winberg 1956), based on a temperature correction factor, $q$, of $1.00,0.78$, and 0.61 for water temperatures 20.0, 23.0 , and $26.0^{\circ} \mathrm{C}$, respectively. The daily feeding dose was distributed manually, in five equal portions. Preliminary observations indicated that fish preferred diet $\mathrm{C}$ to diet F. To avoid a situation in which fish consumed diet $\mathrm{F}$ less effectively than diet $\mathrm{C}$, in group FC, the dry diet was offered to fish at 08:00, 11:00 and 14:00, while natural food was given at 17:00 and 20:00. The experimental aquaria were illuminated from 08:00 to 21:00. The illumination measured on the water surface was about $7001 x$.

Experimental setup. The experiment duration was also adjusted based on the experimental temperatures to avoid comparison of fish of different physiological age and size. Adjustments were made in a manner similar to that used for the daily feeding rates. The experiment lasted 92, 72, and 56 days at $20.0,23.0$, and $26.0^{\circ} \mathrm{C}$, respectively.

The experiment was conducted in 27 experimental aquaria included in three separate, but identical, recirculating aquaculture systems, one for each temperature. Each system included triplicated experimental aquaria for the three dietary groups. Fish were kept in 20 L flowthrough glass aquaria with a continuous flow rate of about $0.25 \mathrm{~L} \cdot \mathrm{min}^{-1}$. The temperature was measured twice a day at 08:00 and 20:00, reaching the following mean values in three treatments: $20.1,23.1$, and $26.0^{\circ} \mathrm{C}$ (Table 3).

Fish quality. During the experiment, the fish survival was monitored daily. On five occasions, all fish were inspected for the presence of visible body deformities: scoliosis,

Table 1

Diet composition of experimental juvenile tench, Tinca tinca

\begin{tabular}{lcc}
\hline \multicolumn{1}{c}{ Diet component } & Aller Futura $(\mathrm{F})$ & Chironomidae larvae $(\mathrm{C})$ \\
\hline Moisture $\left[\mathrm{g} \cdot \mathrm{kg}^{-1} \mathrm{WM}\right]$ & $81 \pm 0$ & $820 \pm 1$ \\
Ash $\left[\mathrm{g} \cdot \mathrm{kg}^{-1} \mathrm{DM}\right]$ & $117 \pm 0$ & $218 \pm 1$ \\
Total lipids $\left[\mathrm{g} \cdot \mathrm{kg}^{-1} \mathrm{DM}\right]$ & $134 \pm 1$ & $346 \pm 7$ \\
Crude protein $\left[\mathrm{g} \cdot \mathrm{kg}{ }^{-1} \mathrm{DM}\right]$ & $645 \pm 3$ & $478 \pm 4$ \\
Phosphorus $\left[\mathrm{g} \cdot \mathrm{kg}^{-1} \mathrm{DM}\right]$ & $12.1 \pm 0.2$ & $3.5 \pm 0.1$ \\
Calcium $\left[\mathrm{g} \cdot \mathrm{kg}^{-1} \mathrm{DM}\right]$ & $20.7 \pm 0.7$ & $78.7 \pm 9.7$ \\
Magnesium $\left[\mathrm{g} \cdot \mathrm{kg}^{-1} \mathrm{DM}\right]$ & $1.3 \pm 0.0$ & $5.1 \pm 0.5$ \\
\hline
\end{tabular}


Table 2

Diets and feeding of experimental juvenile tench, Tinca tinca

\begin{tabular}{|c|c|c|c|c|c|c|c|c|c|c|c|c|c|c|c|}
\hline \multirow{3}{*}{$\frac{\text { Parameter }}{\text { Diet }}$} & \multirow{3}{*}{ Day } & \multicolumn{4}{|c|}{ Group } & \multirow{3}{*}{ Day } & \multicolumn{4}{|c|}{ Group } & \multirow{3}{*}{ Day } & \multicolumn{4}{|c|}{ Group } \\
\hline & & \multirow{2}{*}{$\frac{\mathrm{F} 20}{\mathrm{~F}}$} & \multicolumn{2}{|c|}{ FC20 } & \multirow{2}{*}{$\frac{\mathrm{C} 20}{\mathrm{C}}$} & & \multirow{2}{*}{$\frac{F 23}{F}$} & \multicolumn{2}{|c|}{$\mathrm{FC} 23$} & \multirow{2}{*}{$\frac{\mathrm{C} 23}{\mathrm{C}}$} & & \multirow{2}{*}{$\frac{F 26}{F}$} & \multicolumn{2}{|c|}{ FC26 } & \multirow{2}{*}{$\frac{\mathrm{C} 26}{\mathrm{C}}$} \\
\hline & & & $\mathrm{F}$ & $\mathrm{C}$ & & & & $\mathrm{F}$ & $\mathrm{C}$ & & & & F & $\mathrm{C}$ & \\
\hline Feed & 1 & 3.3 & 2.0 & 16.6 & 41.5 & 1 & 4.2 & 2.5 & 21.1 & 52.8 & 1 & 5.4 & 3.2 & 27.1 & 67.9 \\
\hline intake & 23 & 1.8 & 1.1 & 9.3 & 25.0 & 18 & 2.2 & 1.4 & 11.4 & 30.7 & 14 & 2.9 & 1.8 & 15.0 & 41.4 \\
\hline & 24 & 3.1 & 1.9 & 15.6 & 39.1 & 19 & 3.9 & 2.3 & 19.7 & 49.1 & 15 & 5.0 & 3.0 & 25.2 & 63.0 \\
\hline & 46 & 2.2 & 1.2 & 9.8 & 25.8 & 36 & 2.4 & 1.3 & 11.3 & 28.9 & 28 & 2.8 & 1.6 & 13.9 & 36.6 \\
\hline & 47 & 2.8 & 1.7 & 14.1 & 35.3 & 37 & 3.7 & 2.2 & 18.6 & 46.6 & 29 & 4.7 & 3.0 & 23.7 & 59.2 \\
\hline & 72 & 2.0 & 1.1 & 9.6 & 24.1 & 54 & 2.6 & 1.4 & 11.9 & 28.5 & 42 & 2.9 & 1.8 & 14.3 & 37.4 \\
\hline & 73 & 2.7 & 1.6 & 13.6 & 34.0 & 55 & 3.4 & 2.0 & 17.1 & 42.8 & 43 & 4.4 & 3.0 & 22.2 & 55.4 \\
\hline & 92 & 1.1 & 0.7 & 6.1 & 13.3 & 72 & 1.6 & 1.1 & 9.2 & 21.8 & 56 & 2.5 & 1.7 & 12.7 & 26.3 \\
\hline
\end{tabular}

Feed intake is expressed in percent of fish biomass per day; $\mathrm{F}=$ dry diet, Aller Futura, Aller Aqua, Denmark; $\mathrm{C}=$ natural food, frozen Chironomidae larvae.

Table 3 consisted of randomly chosen fish individuals divided into

Temperature values recorded during feeding experiments on juvenile tench, Tinca tinca

\begin{tabular}{ccccc}
\hline & \multicolumn{4}{c}{ Parameter } \\
\cline { 2 - 4 } Group & \multirow{4}{c}{ Temperature [ $\left.{ }^{\circ} \mathrm{C}\right]$} & \\
\cline { 3 - 4 } & & Mean \pm SD & Range & \\
\cline { 3 - 4 } F20 & 184 & $20.1 \pm 0.2$ & $19.4-21.2$ & \\
FC20 & 184 & $20.1 \pm 0.2$ & $19.4-21.2$ & 1.00 \\
C20 & 184 & $20.0 \pm 0.2$ & $19.4-21.1$ & \\
F23 & 144 & $23.1 \pm 0.2$ & $22.4-23.6$ & \\
FC23 & 144 & $23.1 \pm 0.2$ & $21.9-23.5$ & 0.78 \\
C23 & 144 & $23.0 \pm 0.2$ & $22.2-23.5$ & \\
F26 & 112 & $26.0 \pm 0.2$ & $24.9-23.7$ & \\
FC26 & 112 & $26.0 \pm 0.2$ & $25.0-26.5$ & 0.61 \\
C26 & 112 & $26.0 \pm 0.2$ & $25.0-26.4$ & \\
\hline
\end{tabular}

$q=$ correction factor for temperature (Winberg 1956).

lordosis, and bending opercle. This procedure was carried out under mild anaesthesia, induced by a $0.5 \mathrm{~g} \cdot \mathrm{L}^{-1}$ water solution of 2-phenoxyethanol (Myszkowski et al. 2003). Initial total length (LT, mm, to the nearest $0.1 \mathrm{~mm}$ ) was determined in fish $(n=135)$ from three randomly chosen aquaria. Initial fresh body weight (BW, g, to $0.01 \mathrm{~g})$ was determined for all experimental fish $(n=1215)$. In order to minimize the number of sacrificed animals, the number of fish taken in a sample was adjusted to a minimum sample weight required to perform chemical analysis. Three samples of ca. 120 fish each (ca. $30 \mathrm{~g} \mathrm{WM}$ per sample) were taken before the experiment for proximate chemical composition analysis, and three samples of 40 fish each (ca. $10 \mathrm{~g} \mathrm{WM}$ per sample) were used for determination of macro-minerals crucial for bone mineralization $(\mathrm{Ca}, \mathrm{P}, \mathrm{Mg})$. At the end of the experiment, two samples of fish from each experimental aquarium were taken, separately, for proximate chemical composition analysis (22-32 individuals) and elemental analysis (4-7 individuals). Each of these samples two subsamples of similar weight. The number of fish in the samples depended on the minimum weight of a sample required for analysis according to "the three Rs" principle. Fish taken in samples were euthanized by an anaesthetic (etomidate) overdose. Moisture was determined after drying at $60^{\circ} \mathrm{C}$ to a constant weight in a desiccator over $\mathrm{NaOH}$; fish dry body mass was measured to the nearest $0.0001 \mathrm{~g}$ (Kamler et al. 2012). The remaining material was air-dried, homogenized in an agate mortar, stored at $-20^{\circ} \mathrm{C}$, homogenized again and dried at $60^{\circ} \mathrm{C}$ to a constant weight. Ash contents were determined from subsamples of $100-150 \mathrm{mg} \mathrm{DM}$ after ashing at $450^{\circ} \mathrm{C}$ in a muffle furnace. Nitrogen content was determined by the standard Kjeldahl technique and total protein was estimated as $\mathrm{N} \times 6.25$. Total lipids were extracted in a Soxhlet apparatus using hexane, and, upon hexane evaporation, measured gravimetrically to the nearest $0.0001 \mathrm{~g}$. Calcium, phosphorus, and magnesium were determined in the whole fish. Approximately 1.5 $\mathrm{g}$ of fish (WW) was weighed for analysis. The material was mineralized with $65 \%$ nitric acid and 30\% hydrogen peroxide in MARS-5 microwave ovens (CEM Corporation, Matthews, NC, USA). The concentration of minerals was determined by using an optical emission spectrometer with inductively coupled plasma (simultaneous ICP-OES, VistaMPX, Varian Medical Systems Inc., Palo Alto, CA, USA). Quality assurance for each series of analyses was provided by the parallel analysis of Certified Reference Material (oyster tissue SRM 1566b, bovine liver SRM 1577b). The mean values with variation among the three measurements of $<10 \%$ were used for interpretation of the results (Novaes et al. 2016).

Water quality. Mean $( \pm$ SD) water quality parameters in the experimental aquaria were as follows: dissolved oxygen, $93 \% \pm 16 \%$ of air saturation $\left(8.43 \pm 1.40 \mathrm{mg} \cdot \mathrm{L}^{-1}\right)$; conductivity, $416 \pm 51 \mu \mathrm{S} \cdot \mathrm{cm}^{-1}$; total ammonia nitrogen, $0.26 \pm 0.15 \mathrm{mg} \cdot \mathrm{L}^{-1}$; nitrites, $0.03 \pm 0.02 \mathrm{mg} \cdot \mathrm{L}^{-1} ; \mathrm{pH}, 8.13 \pm$ 0.14 ; calcium, $72.0 \pm 9.3 \mathrm{mg} \cdot \mathrm{L}^{-1}$; phosphates, $0.42 \pm 0.11$ $\mathrm{mg} \cdot \mathrm{L}^{-1}$; and magnesium, $12.0 \pm 4.3 \mathrm{mg} \cdot \mathrm{L}^{-1}$. Differences in the water quality parameters were not significant among experimental groups $(P>0.05)$. 
Data collection. Relative growth rates (RGR, \% per day) were calculated according to the formula

$$
\mathrm{RGR}=100 \times\left(\mathrm{e}^{G}-1\right)
$$

where $G=\left(\ln \mathrm{BW}_{\mathrm{f}}-\ln \mathrm{BW}_{\mathrm{i}}\right) \times d^{-1}, \mathrm{BW}_{\mathrm{f}}$ and $\mathrm{BW}_{\mathrm{i}}$ were the final and initial mean body weights of the fish, respectively, and $d$ was the duration of rearing in days (Myszkowski 1997). Due to the large difference in hydration of the diets comprising Futura and Chironomidae larvae, Feed conversion ratio $\left(\mathrm{FCR}_{\mathrm{dry}}\right)$ was computed in terms of dry matter of the diet and wet matter of the fish body.

Statistical analyses. Analysis of variance (ANOVA), analysis of covariance (ANCOVA), and regression analysis were performed using Statistica 8.0 (StatSoft Inc., Tulsa, OK, USA). Percentage values were arc-sine transformed before analysis. All variables were analysed by two-way ANOVA (mean water temperature and diet) for each variable to determine significant main effects and interactions $(P \leq 0.05)$. The ANOVA was followed by a Tukey's HSD test to compare treatment means. Results were considered significant at the 0.05 probability level.

\section{RESULTS}

Fish survival and body deformities. The final survival rates in all groups ranged from $97.1 \%$ to $100.0 \%$ (Table 4). Body deformities occurred in all groups of fish fed dry feed (Fig. 1). The highest mean incidence of deformities (IDef), 89.8\%, was observed in group F26. In fish fed the $\mathrm{C}$ diet, deformities occurred only in group C20 (0.8\%).

Fish growth and food utilization. Fish accepted all of the experimental diets well, and voluntary intake of food at a single feeding was never longer than $15 \mathrm{~min}$. The greatest BW gain was found in all dietary groups at 23 and $26^{\circ} \mathrm{C}$, while the highest growth rates occurred in groups F26 and FC26 (Table 4). The lowest mean FCR values, 1.12-1.51, were found in groups fed dry diet exclusively.

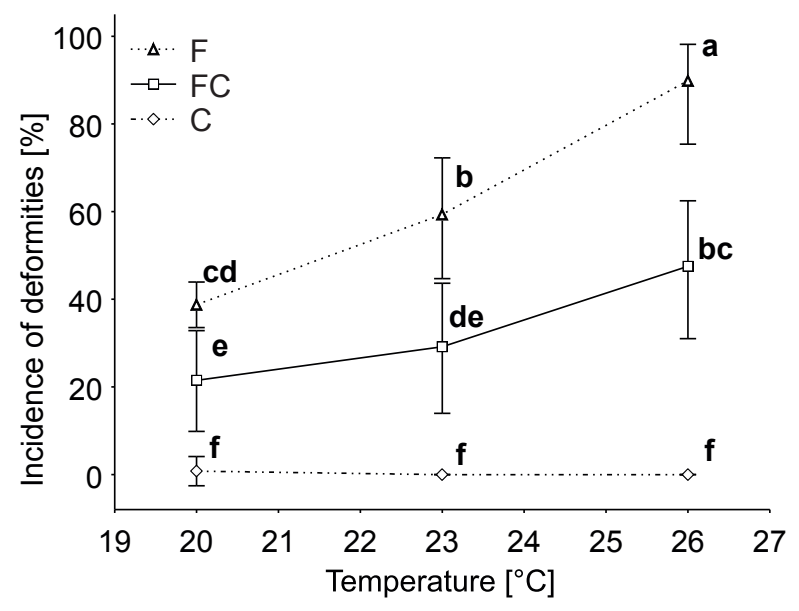

Fig. 1. Incidence of body deformities in juvenile tench, Tinca tinca, fed three different diets (commercial starter diet Aller Futura, frozen larvae of Chironomidae, or a combination of these diets in a $3 \div 2$ ratio) at $20^{\circ} \mathrm{C}, 23^{\circ} \mathrm{C}$, and $26^{\circ} \mathrm{C}$; Values (mean $\pm 95 \%$ confidence limits) marked with different letters were significantly different at $P \leq 0.05$ (Tukey's HSD test, $n=3$ )

Fish body chemical composition. Significant differences were found among experimental groups for all analysed fish body components. Protein content was the highest in groups C23 and C26, while lipid content was the highest in groups C23 and FC23 (Table 5). The lowest moisture values and the greatest ash, $\mathrm{P}$, and $\mathrm{Mg}$ values were found in fish groups fed exclusively diet $\mathrm{C}$.

Factorial analysis and correlations. Two-way ANOVA analysis indicated a significant influence of diet on all measured parameters, except for survival and the $\mathrm{Ca} \div \mathrm{Mg}$ ratio (Table 6). Temperature also influenced most of the measured parameters, with the exceptions of $\mathrm{P}$ and the $\mathrm{Ca} \div \mathrm{Mg}$ ratio. Highly significant interaction of the

Table 4

Final survival, growth, and feed utilization in juvenile tench, Tinca tinca, fed commercial starter diet Futura (F) frozen larvae of Chironomidae (C), or combination of these diets in ratio of $3 \div 2$ (FC) in relation to dry matter content for 92 days, 72 days, and 56 days at $20^{\circ} \mathrm{C}, 23^{\circ} \mathrm{C}$, and $26^{\circ} \mathrm{C}$, respectively

\begin{tabular}{|c|c|c|c|c|c|}
\hline \multirow[b]{2}{*}{ Group } & \multicolumn{5}{|c|}{ Parameter } \\
\hline & Survival [\%] & BWG [g] & $\mathrm{BG}[\mathrm{g}]$ & $\begin{array}{c}\text { RGR } \\
{\left[\% \cdot d^{-1}\right]}\end{array}$ & $\begin{array}{c}\text { FCR }_{\text {dry }} \\
{\left[\mathrm{g}_{\mathrm{DM}} \cdot \mathrm{g}_{\mathrm{WM}}{ }^{-1}\right]}\end{array}$ \\
\hline F20 & $99.8^{\mathrm{a}}$ & $0.89 \pm 0.14^{\mathrm{f}}$ & $39.6 \pm 6.6^{f}$ & $1.71 \pm 0.12^{\mathrm{e}}$ & $1.51 \pm 0.23^{\text {de }}$ \\
\hline $\mathrm{FC} 20$ & $100.0^{\mathrm{a}}$ & $1.13 \pm 0.15^{\mathrm{de}}$ & $50.9 \pm 6.7^{\mathrm{de}}$ & $1.94 \pm 0.11^{\mathrm{d}}$ & $1.97 \pm 0.26^{\mathrm{c}}$ \\
\hline $\mathrm{C} 20$ & $97.1^{\mathrm{a}}$ & $1.01 \pm 0.00^{\mathrm{ef}}$ & $43.8 \pm 0.6^{\mathrm{ef}}$ & $1.83 \pm 0.01^{\mathrm{de}}$ & $3.18 \pm 0.05^{\mathrm{a}}$ \\
\hline F23 & $100.0^{\mathrm{a}}$ & $1.25 \pm 0.13^{\mathrm{bcd}}$ & $56.3 \pm 5.7^{\mathrm{bcd}}$ & $2.59 \pm 0.13^{\mathrm{c}}$ & $1.22 \pm 0.13^{\mathrm{ef}}$ \\
\hline $\mathrm{FC} 23$ & $99.8^{\mathrm{a}}$ & $1.45 \pm 0.18^{\mathrm{ab}}$ & $64.9 \pm 8.4^{\mathrm{abc}}$ & $2.78 \pm 0.14^{\mathrm{c}}$ & $1.77 \pm 0.21^{\mathrm{cd}}$ \\
\hline $\mathrm{C} 23$ & $99.8^{\mathrm{a}}$ & $1.40 \pm 0.13^{\mathrm{abc}}$ & $62.7 \pm 6.1^{\mathrm{abc}}$ & $2.72 \pm 0.10^{\mathrm{c}}$ & $2.66 \pm 0.25^{\mathrm{b}}$ \\
\hline F26 & $99.8^{\mathrm{a}}$ & $1.50 \pm 0.10^{\mathrm{a}}$ & $66.8 \pm 5.5^{\mathrm{ab}}$ & $3.60 \pm 0.10^{\mathrm{a}}$ & $1.12 \pm 0.09^{\mathrm{f}}$ \\
\hline FC26 & $99.5^{\mathrm{a}}$ & $1.56 \pm 0.14^{\mathrm{a}}$ & $69.1 \pm 4.9^{\mathrm{a}}$ & $3.69 \pm 0.15^{\mathrm{a}}$ & $1.77 \pm 0.13^{\mathrm{cd}}$ \\
\hline $\mathrm{C} 26$ & $100.0^{\mathrm{a}}$ & $1.21 \pm 0.07^{\mathrm{cde}}$ & $54.5 \pm 3.3^{\mathrm{cd}}$ & $3.28 \pm 0.10^{\mathrm{b}}$ & $2.94 \pm 0.18^{\mathrm{ab}}$ \\
\hline
\end{tabular}

$\mathrm{BWG}=$ body weight gain, $\mathrm{BG}=$ biomass gain, $\mathrm{RGR}=$ relative growth rate, $\mathrm{FCR}=$ food conversion ratio; Values are mean \pm standard deviation; Mean values in the same row not sharing a common superscript letter are significantly different (Tukey's HSD test, $P \leq 0.05, n=3$ ). 
analysed factors was found to affect the whole-body ash content of the fish and incidence of body deformities.

For the pooled data, IDef was strongly dependent on body ash content $\left(r^{2}=0.833, P<10^{-6}, n=54\right)$. For each dietary group (pooled results of each diet separately for all temperatures), the same significant relation was found in groups where fish were fed the dry diet: in F groups $\left(r^{2}=\right.$ $0.5943, P<0.01, n=18)$, and in FC groups $\left(r^{2}=0.407\right.$, $P<0.01, n=18)$ (Fig. 2). For the pooled results $(n=54)$, IDef was significantly correlated with the ratios of $\mathrm{Ca} \div \mathrm{P}$ $\left(r^{2}=0.352, P<10^{-5}\right)$ and $\mathrm{Mg} \div \mathrm{P}\left(r^{2}=0.198, P<0.001\right)$. Likewise, body ash content was significantly correlated with $\mathrm{Ca} \div \mathrm{P}\left(r^{2}=0.222, P<0.001\right)$ and $\mathrm{Mg} \div \mathrm{P}\left(r^{2}=0.093\right.$, $P<0.05)$. Similar significant correlations of IDef and $\mathrm{Ca} \div \mathrm{P}$ or $\mathrm{Mg} \div \mathrm{P}$ were also found for the $\mathrm{F}$ groups (Figs. 3 and 4), but were not significant for groups fed the FC and $\mathrm{C}$ diets. No significant correlation between body ash and $\mathrm{Ca} \div \mathrm{P}$ or body ash and $\mathrm{Mg} \div \mathrm{P}$ ratio was found in any dietary group $(P>0.05)$.

\section{DISCUSSION}

Fish growth and physiological age. Water temperature is a very interesting and important variable for research studies, due to its crucial role in the growth and development of poikilothermic organisms. However, the broad, multidimensional, and not necessarily parallel effects of temperature make this factor difficult to study. Therefore, most studies to date have been focused on temperature-growth or temperature-food utilization responses. A common practice is to compare fish growth

Table 5

Whole-body chemical composition of juvenile tench, Tinca tinca

\begin{tabular}{|c|c|c|c|c|c|c|c|c|c|c|}
\hline \multirow[b]{2}{*}{ Group } & \multirow[b]{2}{*}{$n$} & \multicolumn{9}{|c|}{ Component } \\
\hline & & $\begin{array}{l}\text { Moisture } \\
{\left[\mathrm{g} \cdot \mathrm{kg}^{-1}\right]}\end{array}$ & $\begin{array}{l}\text { Protein } \\
{\left[\mathrm{g} \cdot \mathrm{kg}^{-1}\right]}\end{array}$ & $\begin{array}{c}\text { Lipid } \\
{\left[\mathrm{g} \cdot \mathrm{kg}^{-1}\right]}\end{array}$ & $\begin{array}{c}\text { Ash } \\
{\left[\mathrm{g} \cdot \mathrm{kg}^{-1}\right]}\end{array}$ & $\begin{array}{c}\mathrm{Ca} \\
{\left[\mathrm{g} \cdot \mathrm{kg}^{-1}\right]}\end{array}$ & $\begin{array}{c}\mathrm{P} \\
{\left[\mathrm{g} \cdot \mathrm{kg}^{-1}\right]}\end{array}$ & $\begin{array}{c}\mathrm{Mg} \\
{\left[\mathrm{g} \cdot \mathrm{kg}^{-1}\right]}\end{array}$ & $\mathrm{Ca} \div \mathrm{P}$ & $\mathrm{Mg} \div \mathrm{P}$ \\
\hline Initial & 3 & $804 \pm 2$ & $145 \pm 2$ & $17.0 \pm 0.3$ & $27.9 \pm 1.1$ & $18.4 \pm 1.1$ & $6.6 \pm 0.5$ & $0.41 \pm 0.08$ & $2.79 \pm 0.35$ & $0.06 \pm 0.00$ \\
\hline $\mathrm{F} 20$ & 6 & $755 \pm 2^{\mathrm{a}}$ & $141 \pm 2^{\mathrm{e}}$ & $82.5 \pm 3.1^{\mathrm{f}}$ & $18.6 \pm 1.3^{\mathrm{bc}}$ & $15.6 \pm 1.6^{b c}$ & $4.4 \pm 0.9^{\mathrm{bc}}$ & $0.28 \pm 0.01^{\mathrm{d}}$ & $3.54 \pm 0.31^{\mathrm{b}}$ & $.01^{\mathrm{b}}$ \\
\hline $\mathrm{FC} 20$ & 6 & $744 \pm 2^{b}$ & $144 \pm 3^{\text {bcd }}$ & $87.8 \pm 0.9^{\mathrm{bcd}}$ & $18.8 \pm 0.7^{\mathrm{b}}$ & $15.1 \pm 1.1^{\mathrm{bc}}$ & $4.9 \pm 0.4^{\mathrm{ab}}$ & $0.30 \pm 0.01^{\mathrm{cd}}$ & $3.11 \pm 0.26^{\mathrm{b}}$ & $0.06 \pm$ \\
\hline $\mathrm{C} 20$ & 6 & $742 \pm 3^{\text {bcd }}$ & $143 \pm 3^{\mathrm{bc}}$ & $85.5 \pm 2.0^{\mathrm{de}}$ & $21.8 \pm 0.4^{\mathrm{a}}$ & $16.7 \pm 1.1^{\mathrm{ab}}$ & $5.2 \pm 0.6^{\mathrm{ab}}$ & $0.33 \pm 0.04^{\mathrm{ab}}$ & $3.26 \pm 0.28^{\mathrm{b}}$ & $0.06 \pm$ \\
\hline $\mathrm{F} 23$ & 6 & $753 \pm 2^{\mathrm{a}}$ & $144 \pm 2^{\text {cde }}$ & $86.7 \pm 1.8^{\mathrm{cd}}$ & $16.4 \pm 0$ & $13.7 \pm 1.9^{c}$ & $3.9 \pm 0.4^{\mathrm{c}}$ & $0.28 \pm 0.03^{\mathrm{d}}$ & $3.52 \pm 0.54^{\mathrm{b}}$ & $0.07=$ \\
\hline $\mathrm{FC} 23$ & 6 & $738 \pm 1^{\mathrm{de}}$ & $146 \pm 4^{\mathrm{bc}}$ & $93.2 \pm 1.3^{\mathrm{a}}$ & $18.5 \pm 0.5^{\mathrm{bc}}$ & $15.6 \pm 1.3^{\mathrm{bc}}$ & $4.6 \pm 0.7^{\mathrm{abc}}$ & $0.29 \pm 0.02^{\mathrm{cd}}$ & $3.43 \pm 0.38^{b}$ & $0.06 \pm 0.01^{\mathrm{b}}$ \\
\hline $\mathrm{C} 23$ & 6 & $737 \pm 2^{\mathrm{e}}$ & $147 \pm 1^{\mathrm{b}}$ & $90.0 \pm 3.7^{b}$ & $21.1 \pm 1.0^{\mathrm{a}}$ & $15.4 \pm 0.7^{\mathrm{bc}}$ & $5.0 \pm 0.4^{\mathrm{ab}}$ & $0.31 \pm 0.01^{\mathrm{abc}}$ & $3.13 \pm 0.25^{\mathrm{b}}$ & $0.06 \pm 0.00^{\mathrm{b}}$ \\
\hline F26 & 6 & $755 \pm 3^{\mathrm{a}}$ & $142 \pm 1^{\mathrm{de}}$ & $83.3 \pm 1.6^{\mathrm{ef}}$ & $15.5 \pm 0.9^{\mathrm{d}}$ & $16.2 \pm 2.1^{\mathrm{ab}}$ & $3.9 \pm 0.5^{\mathrm{c}}$ & $0.30 \pm 0.03^{\mathrm{cd}}$ & $4.16 \pm 0.36^{\mathrm{a}}$ & $0.08 \pm 0.00^{\mathrm{a}}$ \\
\hline $\mathrm{FC} 26$ & 6 & $743 \pm 8^{\mathrm{bc}}$ & $145 \pm 2^{\mathrm{bcd}}$ & $88.8 \pm 3.1^{\mathrm{bc}}$ & $17.7 \pm 0.9^{c}$ & $15.7 \pm 1.8^{\mathrm{abc}}$ & $4.6 \pm 0.2^{\mathrm{abc}}$ & $0.31 \pm 0.02^{\mathrm{bc}}$ & $3.45 \pm 0.41^{\mathrm{b}}$ & $0.07 \pm 0.01^{\mathrm{ab}}$ \\
\hline $\mathrm{C} 26$ & 6 & $740 \pm 4^{\text {cde }}$ & $150 \pm 2^{\mathrm{a}}$ & $87.0 \pm 1.8^{\mathrm{cd}}$ & $21.5 \pm 0.7^{\mathrm{a}}$ & $17.6 \pm 1.8^{\mathrm{a}}$ & $5.3 \pm 0.9^{\mathrm{a}}$ & $0.34 \pm 0.03^{\mathrm{a}}$ & $3.35 \pm 0.39^{b}$ & $0.06 \pm 0.01^{\mathrm{b}}$ \\
\hline
\end{tabular}

All data expressed in wet matter; Values are mean \pm standard deviation; Mean values in the same row not sharing the same subscript are significantly different (Tukey's HSD test, $P \leq 0.05$ ).

Table 6

Two-way ANOVA results on effects of diet and temperature on growth, food utilization efficiency, chemical body composition and incidence of body deformities in juvenile tench, Tinca tinca

\begin{tabular}{|c|c|c|c|c|c|c|}
\hline \multirow{2}{*}{ Parameter } & \multicolumn{2}{|c|}{ Diet } & \multicolumn{2}{|c|}{ Temperature } & \multicolumn{2}{|c|}{ Diet $\times$ temp } \\
\hline & $F 2$ & $P$ & $F 2$ & $P$ & $F 4$ & $P$ \\
\hline BWG [g] & 4.21 & $<0.05$ & 56.21 & $<0.01$ & 5.43 & $<0.05$ \\
\hline $\operatorname{RGR}\left[\% \cdot \mathrm{d}^{-1}\right]$ & 7.52 & $<0.05$ & 503.20 & $<0.01$ & 4.27 & $>0.05$ \\
\hline $\mathrm{FCR}_{\text {dry }}$ & 8.82 & $<0.01$ & 184.49 & $<0.01$ & 1.10 & $>0.05$ \\
\hline Moisture $\left[\mathrm{g} \cdot \mathrm{kg}^{-1}\right]$ & 93.00 & $<0.01$ & 8.00 & $<0.01$ & 1.00 & $>0.05$ \\
\hline Protein $\left[\mathrm{g} \cdot \mathrm{kg}^{-1}\right]$ & 23.30 & $<0.01$ & 4.60 & $<0.05$ & 2.7 & $<0.05$ \\
\hline Lipid $\left[\mathrm{g} \cdot \mathrm{kg}^{-1}\right]$ & 31.67 & $<0.01$ & 22.81 & $<0.01$ & 0.95 & $>0.05$ \\
\hline Ash $\left[\mathrm{g} \cdot \mathrm{kg}^{-1}\right]$ & 147.68 & $<0.01$ & 15.78 & $<0.01$ & 5.23 & $<0.01$ \\
\hline $\mathrm{Ca}\left[\mathrm{g} \cdot \mathrm{kg}^{-1}\right]$ & 10.02 & $<0.05$ & 11.51 & $<0.05$ & 1.31 & $>0.05$ \\
\hline $\mathrm{P}\left[\mathrm{g} \cdot \mathrm{kg}^{-1}\right]$ & 14.55 & $<0.01$ & 1.56 & $>0.05$ & 0.60 & $>0.05$ \\
\hline $\operatorname{Mg}\left[\mathrm{g} \cdot \mathrm{kg}^{-1}\right]$ & 16.08 & $<0.01$ & 4.44 & $<0.05$ & 0.16 & $>0.05$ \\
\hline $\mathrm{Ca} \div \mathrm{P}$ & 9.51 & $<0.01$ & 4.88 & $<0.05$ & 0.16 & $>0.05$ \\
\hline $\mathrm{Mg} \div \mathrm{P}$ & 5.30 & $<0.01$ & 4.98 & $<0.05$ & 0.28 & $>0.05$ \\
\hline $\mathrm{Ca} \div \mathrm{Mg}$ & 2.64 & $>0.05$ & 0.86 & $>0.05$ & 3.14 & $<0.05$ \\
\hline IDef [\%] & 368.77 & $<0.01$ & 82.07 & $<0.01$ & 33.27 & $<0.01$ \\
\hline
\end{tabular}

All data expressed in wet matter, with exception for $\mathrm{FCR}_{\mathrm{dry}}$ (g of dry matter $\cdot \mathrm{g}$ of wet matter $\left.{ }^{-1}\right) . F 2=F($ d.f. $=2), F 4=F($ d.f. $=4)$, $\mathrm{BWG}=$ body weight gain, $\mathrm{RGR}=$ relative growth rate, $\mathrm{FCR}=$ food conversion ratio, $\mathrm{IDef}=$ incidence of deformities . 


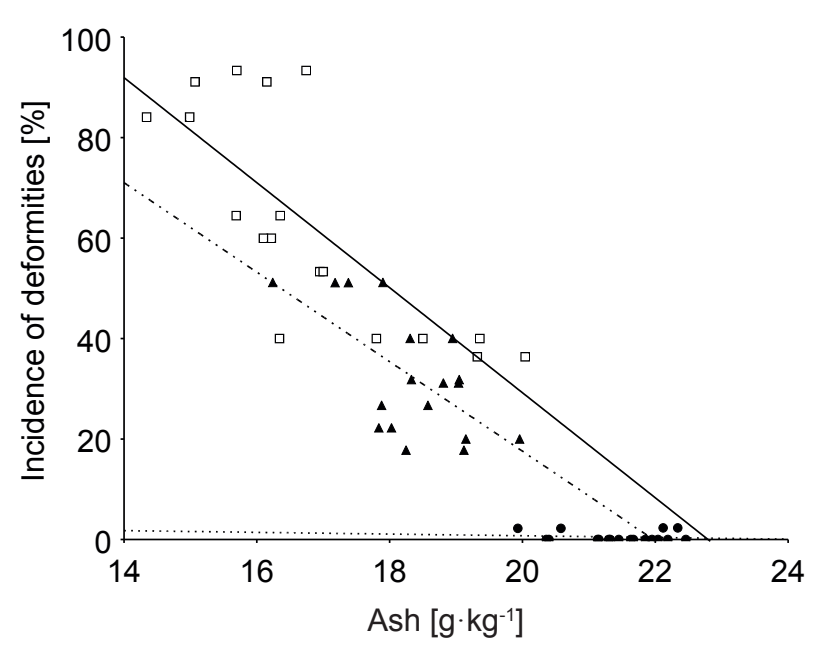

Fig. 2. Linear correlation of the final incidence of body deformities and final ash body content $(P<0.05)$ for juvenile tench, Tinca tinca, fed the commercial starter diet Aller Futura (squares; $y=-10.45 x+238.29 ; P$ $\left.=10^{-4} ; r^{2}=0.59\right)$, frozen larvae of Chironomidae (circles; $y=-0.17 x+4.14 ; P=0.61 ; r^{2}=0.02$ ), or a combination of these diets in a $3 \div 2$ ratio (triangles; $y$ $\left.=-8.91 x+195.75 ; P=0.004 ; r^{2}=0.41\right)$ in relation to dry matter content for 92 days, 72 days, and 56 days at $20^{\circ} \mathrm{C}, 23^{\circ} \mathrm{C}$, and $26^{\circ} \mathrm{C}$, respectively (pooled data)

rates at different water temperatures over the same period. This approach may give useful, practical information; however it leads to a situation in which fish of different physiological age are compared. Younger and smaller fish are known to grow faster than older and larger individuals. Consequently, the effects of an increase in temperature on growth could be underestimated. Similar errors can appear when the effects of temperature on the body chemical composition are being considered. This seems especially important during the early life stages of fish, when their anatomy and physiology change considerably (Kamler 1992, Teletchea et al. 2009).

There are a few commonly employed methods to determine the physiological age of fish. The physiological age of fish can be calculated by means of degree-days [DD], effective degree-days $\left[\mathrm{DD}_{\text {eff }}\right]$, or as a function of standard metabolic rate (SMR) at different temperatures. The $\mathrm{DD}_{\text {eff }}$ method is currently considered the most reliable indicator of fish development (Weltzien et al. 1999). However, $\mathrm{DD}_{\text {eff }}$ is a species-specific indicator. Therefore, in the presently reported study we applied a more universal method and adjusted the methodological approach to different temperatures according to the SMR of fish presented by Krogh's normal curve (Winberg 1956). A notable limitation of the use of a metabolic scale based on Krogh's standard metabolism curve for growth and chemical body composition of fish can appear at high water temperatures that are close to the optimum for growth (OGT). Fish growth rate increases with temperature reaches a maximum value at the OGT. Above the OGT, the growth rate decreases with increasing water temperatures. Therefore, at temperatures close to the OGT, growth and

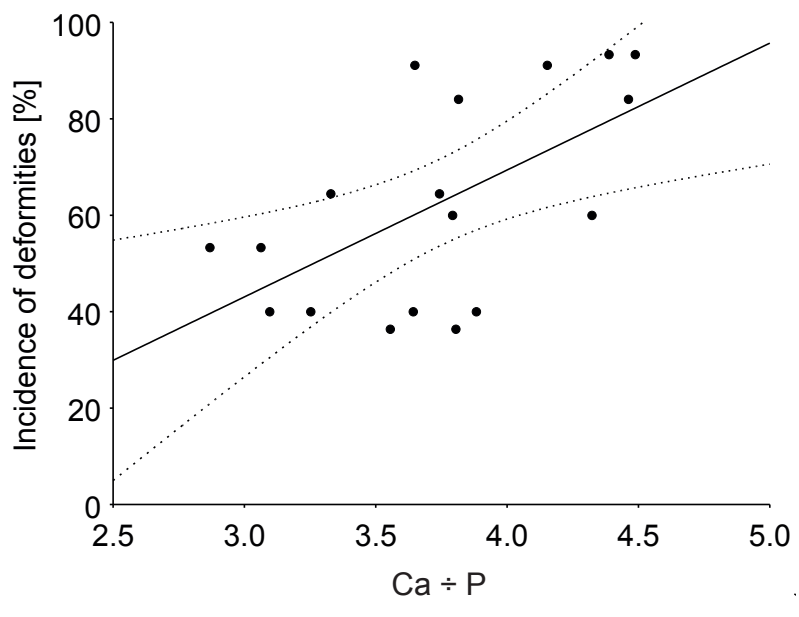

Fig. 3. Linear correlation of the final incidence of body deformities and the $\mathrm{Ca} \div \mathrm{P}$ ratio $(y=26.32 \mathrm{x}-35.89 ; P=$ $0.009 ; r^{2}=0.36$ ) for juvenile tench, Tinca tinca, fed the commercial starter diet Aller Futura (F) for 92 days, 72 days, and 56 days at $20^{\circ} \mathrm{C}, 23^{\circ} \mathrm{C}$, and $26^{\circ} \mathrm{C}$, respectively (pooled data)

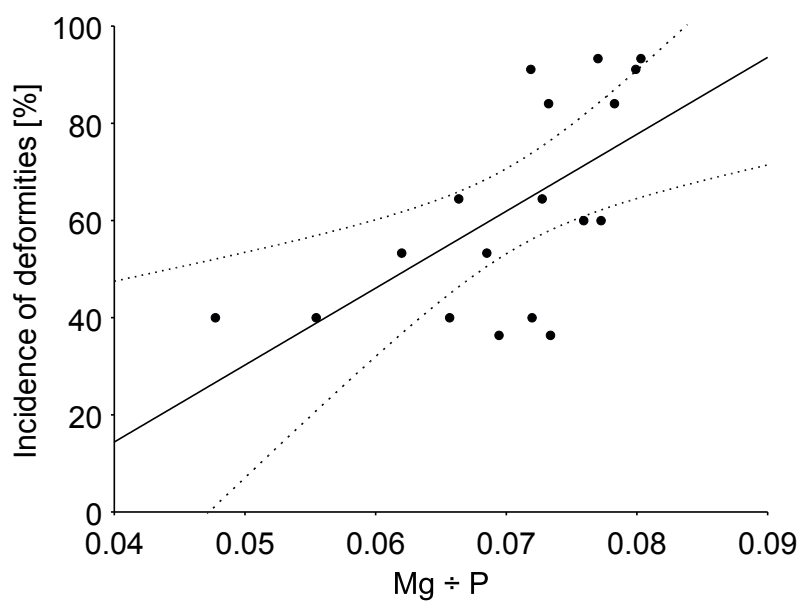

Fig. 4. Linear correlation of the final incidence of body deformities and the $\mathrm{Mg} \div \mathrm{P}$ ratio $(y=1583.27 x-48.92$; $P=0.006 ; r^{2}=0.39$ ) for juvenile tench, Tinca tinca, fed the commercial starter diet Futura (F) for 92 days, 72 days, and 56 days at $20^{\circ} \mathrm{C}, 23^{\circ} \mathrm{C}$, and $26^{\circ} \mathrm{C}$, respectively (pooled data)

food consumption could deviate considerably from the expected values. To avoid this phenomenon in our study, the maximum water temperature was set at $26^{\circ} \mathrm{C}$, while the OGT for juvenile tench is about $28^{\circ} \mathrm{C}$.

The growth results obtained in this study at 23 and $26^{\circ} \mathrm{C}$ fit well with Krogh's curve. At $23^{\circ} \mathrm{C}$, RGR was about $0.77 \cdot \mathrm{RGR}$ at $26^{\circ} \mathrm{C}$ (for all pooled feeding groups), while Winberg's $q$ factor for $26^{\circ} \mathrm{C}$ was $0.78 \cdot q$ for $23^{\circ} \mathrm{C}$ (Table 3). However, at $20^{\circ} \mathrm{C}$ RGR the results were $0.68 \cdot \mathrm{RGR}$ at $23^{\circ} \mathrm{C}$, a value that was slightly lower than the value predicted on the basis of comparison of the $q$ factors for these two temperatures (0.78). The growth rate results were mirrored by $\mathrm{BW}$ gain of fish during the 
experiment. The highest final BW gains were recorded at 23 and $26^{\circ} \mathrm{C}$, whereas BW gain was considerably lower at $20^{\circ} \mathrm{C}$. Nevertheless, we can assume that adjusting the food rations and experiment duration based on temperature and according to Krogh's curve considerably mitigated body size differences among different temperature groups related to the different physiological ages of the fish.

Differences in the physiological ages of the fish on the final day of the experiment also seem to have been successfully mitigated in this study. The presently reported experiment lasted between 56 and 92 days, depending on the water temperature. According to Kamler (2002), the temperature of physiological zero $\left(t_{0}\right)$, the temperature at which development is theoretically arrested, is equal to $11.7^{\circ} \mathrm{C}$ for tench. Thus, the effective water temperature for development, calculated as the differences between the actual water temperature and $t_{0}$, in the current experiment were $8.3^{\circ}, 11.3^{\circ}$, and $14.3^{\circ}$ for 20,23 , and $26^{\circ} \mathrm{C}$, respectively. By multiplying the values of the effective water temperature by the number of experimental days, we found that our experiment lasted from about $764 \mathrm{DD}_{\text {eff }}$ in group C20 to about $821 \mathrm{DD}_{\text {eff }}$ in groups F23 and $\mathrm{FC} 23$. As a result, the maximum difference in the physiological age of fish reared at different temperatures at the end of the experiment was $57 \mathrm{DD}_{\text {eff }}$. For a hypothetical experiment lasting 56 days at 20,23 , and $26^{\circ} \mathrm{C}$, the duration of the experiment in terms of developmental progress would be $465 \mathrm{DD}_{\text {eff }}, 638 \mathrm{DD}_{\text {eff }}$, and $801 \mathrm{DD}_{\text {eff' }}$ In this case, the maximum physiological age difference at the end of the experiment would have been $336 \mathrm{DD}_{\text {eff }}$. We would obtain only slightly better results if we applied the DD scale to calculate the duration of the experiment. In this case the maximum physiological age difference at the end of a hypothetical experiment lasting 56 days at $26^{\circ} \mathrm{C}, 63$ days at $23^{\circ} \mathrm{C}$ and 73 days at $20^{\circ} \mathrm{C}$, would have been $197 \mathrm{DD}_{\text {eff }}$. Thus, the model applied in our study proved to be an effective solution to considerably mitigate differences in fish developmental progress, and thus physiological age, at the end of the experiment.

Food utilization efficiency. Water temperature had a similar influence on $\mathrm{FCR}_{\mathrm{dry}}$ compared with its impact on fish growth. For all diets, the best results were found at $26^{\circ} \mathrm{C}$ and/or $23^{\circ} \mathrm{C}$, whereas at $20^{\circ} \mathrm{C}, \mathrm{FCR}_{\text {dry }}$ was significantly higher (Table 4). These results indicate that the metabolic rate of fish at $20^{\circ} \mathrm{C}$ differed considerably from the values expected from Krogh's curve. This effect was probably not the direct result of a significantly lower SMR than that expected at the lowest water temperature, but rather because the active metabolism did not decrease with water temperature as rapidly as SMR.

Body deformities and chemical body composition. Elevated temperatures and photoperiod manipulation to speed up growth are considered the major environmental factors that cause skeletal deformities in fish, while among the nutritional factors phosphorus nutrition appears the most important (Fjelldal et al. 2012). Fish diet and water temperature both significantly influenced the incidence of body deformities in juvenile tench (Table 6). Moreover, a significant positive interaction between these factors was observed. In all fish groups fed the dry diet, the incidence of deformities was high $(21.5 \%-89.5 \%)$, whereas it was negligible $(\leq 0.8 \%)$ in groups of fish fed natural food, regardless of the water temperature. This comparison suggests the assumption that, in our experiment, fish diet was the factor inducing body deformities, while water temperature only modified the effects of the dietary factor.

Body ash content was influenced by water temperature in a manner similar to that of the incidence of body deformities (Table 6). It is, therefore, unsurprising that the incidence of body deformities had a significant negative correlation with the body ash content (Fig. 2). Body ash is used to assess the amount of minerals incorporated into fish tissues. Thus, low body ash content may be considered a sensitive indicator of improper mineralization of the fish skeleton. In fish groups where the incidence of body deformities was high $(>20 \%)$, the mean body ash content was lower than $19 \mathrm{~g} \cdot \mathrm{kg}^{-1}$ of WM, whereas in other groups, where deformities occurred incidentally, it was significantly higher $\left(>21 \mathrm{~g} \cdot \mathrm{kg}^{-1}\right)$.

Higher ash content was correlated with higher $\mathrm{Ca}$, $\mathrm{P}$, and $\mathrm{Mg}$ contents (Table 5). However, ANOVA analysis did not reveal that the $\mathrm{P}$ content in the fish body was influenced by the water temperature, whereas it did show that the content of $\mathrm{Ca}$ and $\mathrm{Mg}$ were both significantly influenced (Table 6). Consequently, we found significant correlations between the ratio of $\mathrm{Ca} \div \mathrm{P}$ and IDef and the ratio of $\mathrm{Mg} \div \mathrm{P}$ and IDef in fish fed exclusively with the dry diet (Figs. 3 and 4). This indicates that P content was significantly influenced only by fish diet, which we are considering to be the major factor inducing deformities in this experiment. However, the content of $\mathrm{Ca}$ and $\mathrm{Mg}$ were influenced by both diet and water temperature.

Thus, we could conclude that with increasing water temperature, the amounts of $\mathrm{Ca}$ and $\mathrm{Mg}$ incorporated into the fish bodies increased considerably faster than P content. This effect was probably caused by poor utilization of dietary $\mathrm{P}$ from the dry diet, which is a phenomenon commonly observed in fish. In stomachless fish, including tench, some sources of dietary $\mathrm{P}$ are especially poorly utilized (Ogino and Takeda 1976). In contrast to P, fish can effectively absorb $\mathrm{Ca}$ and $\mathrm{Mg}$ from the water. Fish diet is usually only a secondary source of $\mathrm{Ca}$ for fish, but in freshwater fish, dietary $\mathrm{Mg}$ is essential to fulfil fish demand (Lall 2002). In the presently reported experiment, the water contained considerable amounts of $\mathrm{Ca}$ (72.0 $\left.\mathrm{mg} \cdot \mathrm{L}^{-1}\right)$ and $\mathrm{Mg}\left(12.0 \mathrm{mg} \cdot \mathrm{L}^{-1}\right)$. Likewise, the fish diets contained high amounts of these elements (Table 1). Consequently, the whole-body Ca content found in fish from this study was quite high $\left(13.7-18.4 \mathrm{~g} \cdot \mathrm{kg}^{-1}\right)$ when compared with the results of Prabhu et al. (2014), where in 40 different experiments with 27 fish species, the wholebody Ca content ranged from 0.6 to $16.4 \mathrm{~g} \cdot \mathrm{kg}^{-1}$ (median value $\left.6.5 \mathrm{~g} \cdot \mathrm{kg}^{-1}\right)$. However, the whole-body content of $\mathrm{Mg}$ in the tench used in this study $\left(0.28-0.41 \mathrm{~g} \cdot \mathrm{kg}^{-1}\right)$ was found to be similar to the median $\left(0.33 \mathrm{~g} \cdot \mathrm{kg}^{-1}\right)$ of the results of 26 studies of 17 species.

Thus, we can conclude that the experimental fish did not suffer from $\mathrm{Ca}$ and/or $\mathrm{Mg}$ deficiencies. However, the 
increases in $\mathrm{Ca} \div \mathrm{P}$ and $\mathrm{Mg} \div \mathrm{P}$ ratios recorded in our experiment, caused by insufficient $\mathrm{P}$ availability, could lead to distortion of the equilibrium between the amounts of these minerals and, as a result, the skeleton formation processes could have been impeded. However, these factors do not explain in full why the water temperature modified the incidence of deformities in fish fed the dry diet and suffering from $\mathrm{P}$ deficiency.

Water temperature is a key factor affecting fish growth rates. The growth rate of an animal may influence the rate of development of P deficiency signs (Sugiura et al. 2004). Vågsholm and Djupvik (1999) found that body deformities developed in Atlantic salmon (Salmo salar L.) more often in fast-growing fish than in slower-growing fish. A similar phenomenon was observed in juvenile tench (Rennert et al. 2003, Kamler et al. 2006). High growth rates require a disproportionate investment in P-rich biosynthetic cellular structures (Woods et al. 2003). Thus, the phosphorus requirements of the slow-growing tench reared at $20^{\circ} \mathrm{C}$ were considerably lower than the requirements of the faster-growing fish at 23 and $26^{\circ} \mathrm{C}$. Thus, to sufficiently balance the higher $\mathrm{P}$ needs, the whole-body concentration of this macro-element should have been higher at water temperatures of 23 and $26^{\circ} \mathrm{C}$, where fish growth was much faster, than at $20^{\circ} \mathrm{C}$. However, we did not detect this phenomenon in our experiment (Table 5). It is possible that the lower incidence of body deformities in fish reared at lower water temperatures could be related to their considerably lower $\mathrm{P}$ requirements at this temperature.

\section{CONCLUSIONS}

We confirmed the hypothesis that water temperature can significantly influence not only the growth and food utilization efficiency in juvenile tench, but also the chemical composition and the incidence of body deformities in fish fed formulated dry diet under controlled conditions. Natural food (larvae of Chironomidae) did not induce body deformities, irrespective of water temperature. Insufficient bioavailability of $\mathrm{P}$ in the dry diet appeared the major factor causing a $\mathrm{P}$ deficiency in the fish and resulting in low body ash content and body deformities. Water temperature appeared to be a factor modifying the P deficiency symptoms in fish fed the dry diet, probably because of its considerable influence on the $\mathrm{P}$ requirements in fish. However, further studies are required to better explain the effects of water temperature on dietary $\mathrm{P}$ utilization and $\mathrm{P}$ requirements in fish.

\section{ACKNOWLEDGMENT}

This study was supported by the S-001 Project of the Inland Fisheries Institute in Olsztyn, Poland.

\section{REFERENCES}

Björnsson B., Tryggvadóttir S.V. 1996. Effects of size on optimal temperature for growth and growth efficiency of immature Atlantic halibut (Hippoglossus hippoglossus L.). Aquaculture 142 (1-2): 33-42. DOI: $10.1016 / 0044-8486(95) 01240-0$
Boglione C., Gavaia P., Koumoundouros G., Gisbert E., Moren M., Fontagné S., Witten P.E. 2013a. A review on skeletal anomalies in reared European fish larvae and juveniles. Part 1: Normal and anomalous skeletogenic processes. Reviews in Aquaculture 5 (Suppl. 1): 99-120. DOI: $10.1111 /$ raq. 12016

Boglione C., Gisbert E., Gavaia P., Witten P.E., Moren M., Fontagné S., Koumoundouros G. 2013b. Skeletal anomalies in reared European fish larvae and juveniles. Part 2: Main typologies, occurrences and causative factors. Reviews in Aquaculture 5 (Suppl. 1): 121-167. DOI: $10.1111 /$ raq. 12016

Brett J.R., Groves T.D.D. 1979. [6] Physiological energetics. Pp. 279-352.

DOI: 10.1016/S1546-5098(08)60029-1. In: Hoar W.S., Randall D.J., Brett J.R. (eds.). Fish Physiology. Vol. 8. Bioenergetics and Growth. Academic Press, New York, USA.

Celada J.D., Aguilera A., García V., Carral J.M., SaezRoyuela M., González R., González Á. 2009. Rearing juvenile tench (Tinca tinca L.) under controlled conditions using Artemia nauplii as supplement to a dry diet. Aquaculture International 17: 565-570.

DOI: $10.1007 / \mathrm{s} 10499-008-9225-3$

Craig J.F. 1985. Aging in fish. Canadian Journal of Zoology 63 (1): 1-8.

DOI: $0.1139 /$ z85-001

Fjelldal P.G., Hansen T., Breck O., Ørnsrud R., Lock E.-J., Waagbø R., Wargelius A., Eckhard Witten P. 2012. Vertebral deformities in farmed Atlantic salmon (Salmo salar L.) - etiology and pathology. Journal of Applied Ichthyology 28 (3): 433-440.

DOI: $10.1111 /$ j.1439-0426.2012.01980.x

García V., Celada J.D., Carral J.M., Sáez-Royuela M., González R., González Á. 2010. Decapsulated Artemia cysts: a suitable dietary supplement for juvenile tench (Tinca tinca L.). Journal of Applied Aquaculture 22 (1): 57-65. DOI: $10.1080 / 10454430903539186$

González-Rodríguez Á., Celada J.D., Carral J.M., Sáez -Royuela M., Fuertes J.B. 2014. Evaluation of a practical diet for juvenile tench (Tinca tinca L.) and substitution possibilities of fish meal by feather meal. Animal Feed Science and Technology 187 (?): 61-67. DOI: 10.1016/j.anifeedsci.2013.10.001

Imsland A.K., Foss A., Sparboe L.O., Sigurdsson S. 2006. The effect of temperature and fish size on growth and feed efficiency ratio of juvenile spotted wolffish Anarhichas minor. Journal of Fish Biology 68 (4): 1107-1122. DOI: $10.1111 / \mathrm{j} .0022-1112.2006 .00989 . \mathrm{x}$

Jobling M. 1994. Respiration and metabolism. Pp. 121145. In: Jobling M. (ed.) Fish Bioenergetics. Chapman and Hall, London, UK.

Kamler E. 1992. Early life history of fish: An energetics approach. Fish and fisheries series. Vol. 4. Chapman and Hall, London, UK.

DOI: $10.1007 / 978-94-011-2324-2$ 
Kamler E. 2002. Ontogeny of yolk-feeding fish: an ecological perspective. Reviews in Fish Biology and Fisheries 12 (1): 79-103.

DOI: $10.1023 / \mathrm{A}: 1022603204337$

Kamler E., Kamiński R., Wolnicki J., Sikorska J., Wałowski J. 2012. Effects of diet and temperature on condition, proximate composition and three major macro elements, $\mathrm{Ca}, \mathrm{P}$ and $\mathrm{Mg}$, in barbel Barbus barbus juveniles. Reviews in Fish Biology and Fisheries 2 (3): 767-777.

DOI: $10.1007 / \mathrm{s} 11160-012-9256-8$

Kamler E., Myszkowski L., Kamiński R., KorwinKossakowski M., Wolnicki J. 2006. Does overfeeding affect tench Tinca tinca (L.) juveniles? Aquaculture International 14 (1): 99-111.

DOI: $10.1007 / \mathrm{s} 10499-005-9018-\mathrm{x}$

Lall S.P. 2002. The minerals. Pp. 259-308. In: Halver J.E., Hardy R.W. (eds.) Fish Nutrition. 3rd edition. Academic Press Inc., San Diego, CA, USA.

Myszkowski L. 1997. Pitfalls using growth rate coefficients. Polish Archives of Hydrobiology 44 (3): 389-396.

Myszkowski L., Kaminski R., Wolnicki J. 2003. Response of juvenile tench, Tinca tinca (L.), to the anaesthetic 2-phenoxyethanol. Journal of Applied Ichthyology 19 (3): 142-145.

DOI: 10.1046/j.1439-0426.2003.00460.x

Novaes C.G., Bezerra M.A., Paranhos da Silva E.G., Pinto dos Santos A.M., Lago da Silva Romão I.L., Santos Neto J.H. 2016. A review of multivariate designs applied to the optimization of methods based on inductively coupled plasma optical emission spectrometry (ICP OES). Microchemical Journal 128: 331-346.

DOI: $10.1016 /$ j.microc. 2016.05 .015

Ogino C., Takeda H. 1976. Mineral requirements in fish. III-Calcium and phosphorus requirements in carp. Bulletin of the Japanese Society of Scientific Fisheries 42 (7): 793-799.

DOI: 10.2331 /suisan.42.793

Peňáz M., Prokeš M., Kouřil J., Hamačkova J. 1989. Influence of water temperature on the early development and growth of tench, Tinca tinca. Folia Zoologica 38 (3): 275-287.

Prabhu P.A.J., Schrama J.W., Kaushik S.J. 2014. Mineral requirements of fish: a systematic review. Reviews in Aquaculture 8 (2): 172-219. DOI: 10.1111/ raq. 12090

Rennert B., Kohlmann K., Hack H. 2003. A performance test with five different strains of tench (Tinca tinca L.) under controlled warm water conditions. Journal of Applied Ichthyology 19 (3): 161-164.

DOI: $10.1046 /$ j.1439-0426.2003.00464.X

Sadler S.E., Friars G.W., Ihssen P.E. 1986. The influence of temperature and genotype on the growth rate of hatchery-reared salmonids. Canadian Journal of Animal Science 66 (3): 599-606.

DOI: $10.4141 /$ cjas86-066
Sugiura S.H., Hardy R.W., Roberts R.J. 2004. The pathology of phosphorus deficiency in fish-A review. Journal of Fish Diseases 27 (5): 255-265. DOI: $10.1111 /$ j.1365-2761.2004.00527.x

Teletchea F., Gardeur J.-N., Kamler E., Fontaine P. 2009. The relationship of oocyte diameter and incubation temperature to incubation time in temperate freshwater fish species. Journal of Fish Biology 74 (3): 652-668.

DOI: 10.1111/j.1095-8649.2008.02160.x

Vågsholm I., Djupvik H.O. 1999. Risk factors for abdominal adhesions in Atlantic salmon, Salmo salar L. Journal of Fish Diseases 22 (1): 53-58.

DOI: 10.1046/j.1365-2761.1999.00137.x

Weltzien F.A., Planas M., Fyhn H.J. 1999. Temperature dependency of early growth of turbot (Scophthalmus maximus L.) and its implications for developmental progress. Journal of Experimental Marine Biology and Ecology 242 (2): 201-210.

DOI: 10.1016/S0022-0981(99)00099-4

Winberg G.G. 1956. Rate of metabolism and food requirements of fishes. Belorussian State University, Minsk. Fisheries Research Board of Canada, Translation Series No. 194.

Witten P.E., Gil-Martens L., Huysseune A., Takle H., Hjelde K. 2009. Towards a classification and an understanding of developmental relationships of vertebral body malformations in Atlantic salmon (Salmo salar L.). Aquaculture 295 (1-2): 6-14. DOI: $10.1016 /$ j.aquaculture.2009.06.037

Wolnicki J., Kamiński R., Myszkowski L. 2003. Effect of supplementation of a dry feed with natural food on growth, condition and size distribution of juvenile tench Tinca tinca (L.). Journal of Applied Ichthyology 19 (3): $157-160$.

DOI: $10.1046 / j .1439-0426.2003 .00468 . x$

Wolnicki J., Korwin-Kossakowski M. 1993. Survival and growth of larval and juvenile tench, Tinca tinca L., fed different diets under controlled conditions. Aquaculture Research 24 (6): 707-713.

DOI: $10.1111 /$ j.1365-2109.1993.tb00649.x

Wolnicki J., Myszkowski L., Korwin-Kossakowski M., Kamiński R., Stanny L.A. 2006. Effects of different diets on juvenile tench, Tinca tinca (L.) reared under controlled conditions. Aquaculture International 14 (1): 89-98.

DOI: $10.1007 / \mathrm{s} 10499-005-9017-\mathrm{y}$

Woods H.A., Makino W., Cotner J.B., Hobbie S.E., Harrison J.F., Acharya K., Elser J.J. 2003. Temperature and the chemical composition of poikilothermic organisms. Functional Ecology 17 (2): 237-245.

DOI: 10.1046/j.1365-2435.2003.00724.X

Received: 19 September 2016 Accepted: 27 January 2017 Published electronically: 31 March 2017 